\title{
Economic Institutions in Ancient Greece and Mesoamerica
}

\section{Stephen A. Kowalewski}

University of Georgia

\begin{abstract}
New studies have led to deeper comprehension of economic variation and change in Late Post-classic Mesoamerica and the Archaic and Classical Greek world. Archaeological data on city-state settlement patterns, specialized production, trade, and household consumption, new archival material, and re-analysis of texts have undermined primitivism, substantivism, and ideal-types. In urbanization and demographic scale the two areas are comparable. Mesoamerican and Greek agricultural production was not simply for subsistence, but was market-oriented and market-dependent. Local and long-distance trade often functioned by market mechanisms. The economies had the capacity for real growth. There are two major differences. The Old World used state-issued coinage as money; Mesoamerica had goods monies. In the Old World the firm, or corporate group for carrying out economic activities, was sometimes larger than in Mesoamerica, where the household was the locus of specialized production. These differences had consequences in the relative capacity for accumulation, appropriation, and inequality.
\end{abstract}

\section{CITY-STATES}

City-states are politically autonomous polities, usually urbanized, having sovereignty over a small territory. Individual city-states are usually components of city-state systems, which are networks of economic, political, and other cultural exchange between multiple city-states, each regulating its membership and resources (Hansen 2000).

Social Evolution \& History, Vol. 19 No. 1, March 2020 21-42

(C) 2020 'Uchitel' Publishing House

DOI: $10.30884 / \mathrm{seh} / 2020.01 .02$ 
Here I compare ancient Greek city-state systems of the Archaic and Classical periods with city-state systems in Mesoamerica, including Late Post-classic highland Oaxaca, Aztec central Mexico, and Classic-period Maya, which are the regions and time periods with the best data coverage.

City-state systems are said to develop from the break-up of larger states or empires (proposed for Europe and elsewhere, Hansen 2000), as a phase of a cycle between large and small states (Marcus 1989), on the interstices or frontiers between competing empires (e.g., Southeast Asia, O'Connor 2000; Europe, Scheidel 2013), as colonies of established states (Mediterranean), or as primary phenomena (Yoffee 2005).

Individual city-state histories are chaotic but city-state systems often experience long-term growth. City-state systems may function or persist because they generate innovation and wealth, which they do by balancing the protection of internal city-state resources against the growth that comes from regional specialization and exchange.

The scholars of Mesoamerica and Archaic and Classical Greece are aware that one cannot generalize to the whole city-state system from the Aztecs or the Athenians, although doing so is surely tempting because these cases are the best documented. City-states vary by local adaptations and place in their larger world-system.

Specialists are also keenly aware that things change. Tikal or Chunchucmil of AD 400 were not the same as they became in AD 700. The Athenian democracy of Pericles in the fifth century BC was gone by the time of Phillip II of Macedonia a hundred years later. Understanding the trends over time, that the Basin of Mexico Aztec state fitfully and incompletely consolidated power in a centralized government through the fifteenth century, and that the size of the largest rural estates in Greece increased from Archaic to Classical to Hellenistic times, is important for understanding process.

\section{MESOAMERICAN AND GREEK CITY-STATES}

Mesoamerican and Greek city-states were roughly the same in territorial and demographic size. Although some scholars are reluctant to compare city-states cross-culturally, citing distinct cultural traditions (Marcus and Sabloff 2008), to me there are sufficient similarities in emic measures of scale to allow productive comparison so that we might get beyond typology to understand behavioral 
process (see also Zuiderhoek 2017, whose aim is to juxtapose the ancient city across cultures and to enter debates about urbanism, the rise of capitalism, and Western exceptionalism).

City-state territories in the Archaic and Classical Greek world were small, usually about 100 or $200 \mathrm{~km}^{2}$ in size, but many were even smaller. Athens was about $2500 \mathrm{~km}^{2}$ (Hansen 2000, 2006; Cornell 2000). From my study of 74 Late Post-classic (AD 13001520) city-states in highland Oaxaca known archaeologically and ethnohistorically (Kowalewski 2020), the mean territory size is about $75 \mathrm{~km}^{2}$ and the largest are about $300 \mathrm{~km}^{2}$. This is similar to the Aztec examples in Central Mexico (Hodge 1984, 1997; Smith 2008). Territories of Classic Maya city-states are defined by glyphic evidence for the seat of a ruler, ajaw, and in some recent work, boundary sites (e.g., Scherer and Golden 2009), and thus are harder to define, but they may be larger, perhaps $2500 \mathrm{~km}^{2}$ (a radius $30 \mathrm{~km}$ more or less [Grube 2000]).

The city-state worlds were also similar in size, with the greater eastern Mediterranean of Classical times roughly $1800 \mathrm{~km}$ across and the same for Mesoamerica, both figures of course subject to criticism since these were open systems with no real borders. The Classic Maya and Classical Aegean systems were approximately the same magnitude, over $500,000 \mathrm{~km}^{2}$ for the latter including the seas, and $250,000 \mathrm{~km}^{2}$ for the former.

Aztec, Oaxacan, and Greek city-state populations have similar ranges, the small just a few thousand people and several major ones with a few hundred thousand (Athens, Tenochtitlán, and Coixtlahuaca). The median Aztec and Oaxacan city-state population of 8,000-10,000 people was higher than in ancient Greece and correspondingly their population densities were higher (sources cited above). Classic Maya city-states may have been not only larger in area but on the whole more populous, yet population densities were probably lower, more like Greece. In Mesoamerica and the Aegean total populations for the city-state systems were over five million but not more than twenty million, that depending on the geographical bounds, and in both cases human populations were growing fairly rapidly (Hansen 2006; Scheidel 2008; Blanton et al. 1993).

Oaxaca and Aztec central Mexico were highly urbanized, with over half of the total population living in city-state capitals (Hodge 
1997 and my Oaxaca sample). Hansen (2006) estimates that just under half of the Greek population lived in city-state capitals, but he shows that in most Greek city-states, especially the smaller ones, the population was concentrated in one central place, while fewer large city-states had more substantial rural populations. Large Maya urban centers like Tikal, Caracol, and Calakmul were of the same magnitude in number of inhabitants as the large cities of ancient Greece.

In Mesoamerica as in ancient Greece the older notion of the purely 'consumer city' has not weathered well against the steady rain of archaeological data showing that a significant portion of a society's production took place in urban centers ( $c f$. Smith 2008; Hansen 2008; Bresson 2016; Zuiderhoek 2017: 48-49). Instead, city-state systems have urban centers with a variety of central place functions, among which production usually figures prominently.

Greek urbanism was somewhat distinct in character from that in Mesoamerica. Greek cities generally were more densely settled. In the Mediterranean most urban inhabitants lived densely packed within fortification walls and the city wall was a major civic expense (Ober 2015: 42-43). Mesoamerican cities were typically not fortified. In most Mesoamerican cities the house lots were larger and the residential pattern was more dispersed. Greek cities generally are more likely to have had a regular plan of streets facilitating movement and exchange.

\section{SOCIAL STRATIFICATION}

As opposed to a two-caste system of rulers and ruled, both Mesoamerica and the Greek world had a substantial social middle. A broad base of households with the means to consume stimulated craft production and trade (Kron 2016). Wealth stratification studies for Greece show low and middle range Gini coefficients for the distribution of landholdings and household income (Bresson 2016: 145; Ober 2011). Similar studies in Late Post-classic Mesoamerica using house sizes and other evidence of material consumption also yield low to middle-range Gini coefficients (Smith et al. 2014; Steere and Kowalewski 2012). Post-Neolithic inequality in wealth is generally higher in the Old World (Kohler et al. 2017) but Classical Greek wealth inequality is lower than in other Old World states. 


\section{GOVERNANCE}

The elements of political structure also run counter to a simple despotic model of rulers and ruled. Greek city-states had relatively wide participation in governance, the indigenous term for this being democracy. Mesoamerican city-states are usually thought of as autocratic monarchies, but political organization here was more complicated than that and more variable. Mesoamerica did not have the broad participation in the highest levels of its states as did ancient Greece, but it did exhibit a wide range of checks on rulers' authority, including governing by council (Tlaxcala, Fargher et al. 2011), rulers' reliance on advisory councils (Blanton and Fargher 2008: 246-248), ideologies of responsibility and egalitarianism (Blanton with Fargher 2016: 231-233), and ritualized humbling and moral instruction for functionaries taking office (Boone 1983: 211). In some cases the state was little involved in local affairs and it was the community of smallholders that retained control of land (Kowalewski et al. 2017). For Classic Maya, civic-ceremonial functions were usually quite dispersed instead of concentrated in a single place. The art and materiality of Classic Maya royal courts emphasizes the theater of state ritual and war while attending rather little to secular civic matters (Inomata and Houston 2001).

\section{ECONOMY}

Mesoamerica lacked livestock, which is protein, fat, leather, wool, manure, hedge against poor harvest, parasite on the food supply, truck, tractor for plow, cart, chariot, and grain mill, badge of male prestige, war machine, casus belli, reservoir of disease, a love and a nuisance - in other words not a benefit on all counts. The Mesoamerican human ecosystem with a population of the tens of millions seems to have done well without livestock.

Mesoamerican agriculture was more land- and labor-intensive. In Oaxaca for example, a person could cultivate a maximum of two hectares with the coa, and one hectare would often yield enough maize for five people (Nicholas 1989). In ancient Greece the minimal farm had to be at least five hectares (Davies 2008: 349; Bresson 2016: 121). These are generalized figures but the difference is clear. Greece relied on mixed, extensive, usually rainfallfed farming and Mesoamerica devoted more labor per unit area of land and emphasized intensive techniques in crop mix and man- 
agement of soil and water. In terms of greatest yields as well as societal structuring, the most important sector of Mesoamerican agriculture was that operated by smallholders who had invested in landesque capital (Hakansson and Widgren 2014; Kowalewski et al. 2017).

In both Mesoamerican and Greek city-states there was considerable specialization and division of labor in agriculture and crafts. In neither were the commoner masses subsistence farmers; instead, households produced differentiated goods and services for the general market and they consumed from the general market. Specialization is seen internally, within the city-state, and it is seen at a larger scale too, where whole city-states or clusters became known for particular goods while importing others. Scheidel's map of population densities in the Aegean world (Scheidel 2008: Map 3.1 ) is one informative proxy for core-periphery structure. Regional specialization has been accounted for in both areas by Ricardian comparative advantage and by core-periphery, world-systems perspectives (Hirth 2016; Kowalewski 2012, 2016; Harris et al. 2016; Bresson 2016; Archibald 2013).

Greeks invested more in transportation. They built roads to handle carts pulled by oxen. A cart might carry a ton of grain $50 \mathrm{~km}$ a day (Bresson 2016: 82). A Mesoamerican tlameme could carry $50 \mathrm{~kg}$ for $40 \mathrm{~km}$ in a day (Hirth 2016: 239-243). Whether the energetic costs of road construction, animal fodder and maintenance, and drivers are lower than those of transport by tlameme is not clear to me.

The Greeks built ships capable of carrying 140 tons (Bresson 2016: 87), a significant difference over the Mesoamerican oceangoing boat (Las Casas 1986: 81), although the costs of ship-building and risks of sea voyaging must also be taken into account. Still, for Mesoamerica we have no evidence equivalent to the regularized trade of grain from peripheries such as the lands bordering the Black Sea to the core in Attika, a distance of a thousand kilometers (Bresson 2016).

In both areas, the household was the typical firm, the unit that allocated and managed labor and resources and made production decisions (for Mesoamerica see Feinman and Nicholas 2000; Hirth et al. 2017; for ancient Greece see Bresson 2016: 188; Zuiderhoek 2017: 136). Mesoamerican specialized activities did alter the land (wetland raised fields, terraces, cacao orchards) and left extensive accumulations of debris (quarries, saltworks, the kilometers of tun- 
nel mines in Zacatecas (Weigand 1968, 1993: 245-311) but these can be accounted for as the aggregate actions of small-scale producers living on-site or nearby. Apart from large-scale longdistance merchant ventures (Sahagún 1975: Book 9) I cannot find evidence of large-scale production enterprises in Mesoamerica. But in Greece in addition to typical household-scale farms, shops, and craft production units, there were also larger workshops, in quarries, mines, larger farms, vineyards, olive orchards, shipbuilding, arsenals, and textiles (Acton 2016; Bresson 2016).

Mines, large estates, vineyards, olive orchards, shipyards, arsenals, and textiles were the same sectors, in which accumulation was possible. That is, owners could make substantial profits that could be reinvested in land, equipment, or labor. The products of the larger enterprises were strategic or world-system goods. Larger enterprises had scalar advantages in competition with small firms in international trade (Acton 2016; Bresson 2016).

Mesoamerica also had world-system goods such as obsidian, cacao, textiles, and salt (Williams 2004; Blanton et al. 2005). However, while their production and handling did lead to intensive specialized activity involving hundreds of households in particular communities, and thus some gains in efficiency through information exchange and organized transport, producer-households maintained control over the production process and profits. If there were a kind of accumulation it resided in the collective or aggregate of the specialist houses.

\section{MARKET EXCHANGE}

The Mesoamerican goods-market systems are well known and attested by ethnohistoric and archaeological information for the Aztecs, Oaxaca, and the Maya (Kowalewski 2016; Hirth and Pillsbury 2013; King 2015; Garraty and Stark 2010). There is textual and linguistic evidence of buying and selling goods, credit, loans, and interest for the Aztecs and the Maya (Hirth 2016; Tokovinine and Beliaev 2013). However, markets for land and labor, in the sense that land and labor could be bought or sold free and clear of their social obligations, in general do not seem to have been institutionalized (Isaac 2013).

The Greek institutions of the agora and the emporium facilitated internal and external trade, respectively. Textual evidence shows that in addition to goods and services, there were regular- 
ized means of trade in land, labor, and capital (Harris et al. 2016; Lyttkens 2013; Zuiderhoek 2017: 140-146). City-states proscribed the selling of land to foreigners, although that practice eroded in Hellenistic times (Bresson 2016). Instruments of credit, debt, and interest, plus means for handling business disputes, lowered transaction costs for long-distance merchants and provided means to allocate capital to profitable sectors. The institutions that made finance easier of course also opened opportunities for rentierism, here meaning owners who could live well off the profits of their properties without being much involved in their management.

\section{MONEY}

Mesoamerica used various goods monies. Although the term 'barter' has been used to describe goods-money transaction, or even haggling or bargaining over price, this is a flagrant violation of meaning generally (Graeber 2011) and especially in Mesoamerica, where market transactions were regularized and prices and equivalents were well known.

State-minted coinage played a major role in the marketization of production factors. It was introduced in Lydia, in western Asia Minor, in the eighth century and by $500 \mathrm{BC}$ had become almost universal in the Greek world as the medium of exchange, standard of value, means of accounting and credit, and way of paying taxes, fees, and fines (Bresson 2016; Davies 2008; Van der Spek 2011). City-state imprimatur guaranteed the metallic weight and value. The state paid for its expenditures in war, construction of facilities, credit, etc., with its coins, which continually added to the amount in circulation. Coinage lowered the costs of transactions where payments were deferred in time or took place across spatial and social boundaries. It facilitated the transfer of value from less profitable to more profitable economic sectors and made it easier to convert value between labor, land, and things. Coinage helped free the factors of production from their social matrix, which was a gain in liquidity and the ability to accumulate.

Mesoamerica had wealth, growth, specialization, urbanization, markets, but was not monetized and did not allow for much accumulation by economic means (as opposed to force). Mesoamerican currencies were relatively less liquid and fungible than the minted silver of the ancient Mediterranean. It is possible, although this proposition is not well established, that goods monies could be 
fundamentally more egalitarian in themselves, perhaps because goods retain some of their use value, or because with multiple types of goods as currencies none is a monopoly money, or because goods money exchanges are more intricate, distributed, and embedded and thus less subject to control by the state or other large actors. Unfortunately we do not have much ethnographic or historical description of how such systems worked.

Apart from its cashless media of exchange, store of value, and means of accounting, a less speculative reason the Mesoamerican economy did not make accumulation easy is because, in many places, often in those that were the richest agriculturally, local communities retained control of smallholder property. Property was thus harder to alienate from its stakeholders. Communal institutions often remained relatively strong, which is the bane of capitalist development and its promoters but also could be said to promote the greatest good for the greatest number. To come to the general point, it is not that Mesoamerica lacked certain key things or institutions, here coinage, a phrasing that implies that it was not up to Western standards of value, but that its market economy worked with different rules, some of which are still unclear to us.

\section{CITY-STATES AS ECONOMIC ACTORS}

Scholars of ancient Greece have documented numerous ways in which states were significant economic actors. State expenditures for war included funding very substantial city fortifications, arms, ships, and soldiers. City-states invested in physical facilities in support of trade (roads, ports, and markets) and in the personnel who regulated trade. City-states provided other public goods and welfare, including 'safety-net' purchases of grain as a hedge against famine. The state had major economic roles to play through its fiscal and monetary actions (Lyttkens 2013; Bresson 2016).

Evidence of direct economic action by city-states in Mesoamerica is harder to come by. Usually it is not known whether rulers' economic behavior was on their own account, that is, the palace as a house, or on behalf of a wider public. Ethnohistoric sources for the Aztecs (Sahagún, principally) can be mined for instances in which the king financed long-distance merchant ventures. These sources also have stories in which the killing of merchants in foreign lands was a casus belli. Aztec kings are said to have awarded estates in conquered lands to favored generals. The greatest atten- 
tion has been paid to the economic effects of the Aztec tax and tribute, close to home and in outlying provinces (Berdan et al. 1996). More generally in Mesoamerica states may have sponsored festivals and provided market services.

In the Mesoamerican and Greek worlds the economic role of states varied considerably. Neither Athens and Sparta, nor Tenochtitlán and Coixtlahuaca, adequately represent the range of collective $v s$. autocratic authority, nor the mainly commercial $v s$. the mainly agricultural interests. The relative sparseness of documentation for Mesoamerica speaks neither for nor against a conclusion that its city-states were less involved in providing economic services.

\section{ECONOMIC GROWTH}

Was the ancient economy capable of real economic growth? Primitivists said no, that if one did see apparent growth that was only Malthusian pace-keeping, that productivity was stagnant because wealth was funneled into elite luxury living rather than general consumption and technological innovation. The debate now seems resolved, as recent studies in the ancient Mediterranean provide empirical evidence for increased rates of general consumption, perhaps 'a growth rate of around 0.4 percent per year over four centuries... unparalleled before the Dutch paradigm two millennia later' (Bresson 2016: 205-206; Morris 2004, 2005; Ober 2011, 2015; Harris and Lewis 2016; Temin 2013). These gains are argued to be linked to increases in the productivity of labor made possible by technological innovations and new markets ( $c f$. Schumpeter 1942) and the totality of all the institutions that developed to lower transaction costs, increase trade, and therefore promoted specialization.

The case for real economic growth in Mesoamerica has advanced more slowly because of the dearth of statistical records and because only a few scholars have addressed it (Stark 2013). Household consumption rates increased many times and in many places. Plausibly the growth in general consumption could be due to increased market integration, trade, and specialization (Kowalewski 2012), but the archaeological research is still weak. Further, the economists' assumption that labor productivity comes from technological innovation has not been evaluated in Mesoamerica.

However, the issue of economic growth is not as straightforward as weighing the pig in October and then in March and concluding that it grew by so many kilos because it was fed grain and drugs. 
Economic growth is hard to define, especially cross-culturally, hard to measure, hard to explain, and hard to untangle from productivity, wealth, consumption, well-being, and value. As many have suggested, including Eugene Odum (1993) and Trawick and Hornborg (2015), quantitative growth may not be such a great thing. These significant issues are beyond the scope of this paper.

\section{WHY THE DIFFERENCES?}

To this point I have argued that the city-state systems of ancient Greece and Mesoamerica were similar in some fundamental economic ways: geographic size, population and population density, urbanization, organization as autonomous city-states controlling internal factors while permitting considerable cross-boundary exchange, market systems for goods and services, core-periphery world-system structure, broad distributions of wealth, and expanding general household consumption.

The key difference between ancient Greece and Mesoamerica is the former system's economic liquidity and capacity for capital accumulation. That is, in the Greek world not only goods and services but property in land and labor, could swim unattached from social bonds. Individual owners could amass capital to assemble large holdings in land, labor, and equipment, at the expense of other people and for their own profit, with the protection of the law, because land, labor, and material things were called private property, not the community's, the state's, or god's property. In Mesoamerica, local institutions held material value in land and labor closer to their social origins.

If the main difference is accumulation and liquidity or fungibility, why did that difference exist? I think the explanation lies not in grains, grapes, olives, silver, or cacao - the things in themselves but in the social relations of production, specifically property, especially property in land and in slaves. First, property in land. Mesoamerican property was held by households but regulated by communities. Mediterranean property could be bought, sold, and alienated. Why this difference in the definition of property? I think it is because Mesoamerican farms and their improvements were small, densely packed together, each farm was individually managed by smallholders, forming landesque capital zones around particular fixed water and soil patches often corresponding to drainage segments (e.g., raised fields, chinampas, small-scale irrigation net- 
works, terrace systems), and in each patch or segment the constituent smallholders belonged to a relatively closed corporate group. This kind of community was not universal in Mesoamerica and there were areas of extensive agriculture where hereditary lords dominated and local communities were not as strong, but the places with the most productive land, the highest degree of rural development, and densest rural populations usually had strong local communities.

Slaves were a minor social category among the Aztecs (Smith and Hicks 2017) and in Mesoamerica generally their economic importance was minimal. But the Mediterranean was the opposite: slavery was widespread, enslaved people were numerous, and their forced labor was essential to the economy. Many scholars have argued that Athenian democracy flourished because of slavery.

In the Classical world enslaved people were chattel property, they could be bought, sold, and worked as their private owners saw fit. Capturing, moving, and selling people from the periphery to the core was a commercial business (Lewis 2016) and slaves were a world-system good. Total numbers of slaves may never be known, but here is a small sampling of authoritative observations and estimates: 'we are entirely in the dark' and 'every polis had plenty' (Hansen 2006: 109); a third (Wood 1988: 42ff.), 40-50 per cent (Bresson 2016: 459), or more than half of the population in the Athens city-state (Lyttkens 2013: 28-29). Across the Mediterranean such approximations translate into millions of enslaved people.

People were enslaved in cities and in the countryside. Many free households used a few slaves for domestic work. Osborne (2010: 85-103) describes the political and economic importance of slaves in Athens. He emphasizes domestic slaves, and slaves in craft manufacture, including metal-working. 'The ergasterion staffed by slaves, owned by an entrepreneur or rentier, and run by a free, freedman, or slave overseer, had unquestionably become the typical nonagrarian productive institution, and could attain significant size' (Davies 2008: 347). In the mines hard slave labor provided the silver that Athens used to make its money, literally. Slaves - perhaps 10,000 to 35,000 - worked in the silver mines of Laurion in Attika (Davis 2008; Lewis 2016). Slaves (helots) were used on polyculture farms in Sparta, where the economy was more agricultural and 
less committed to international commerce (Lewis 2016). Archaeological and textual evidence assembled by Morris and Papadopoulus (2005; see also Bresson 2016: 122-127, 212-213; Davies 2008; Thompson 2003) strongly associates slave labor and intensive agriculture, especially on the larger estates in Attika.

People who were captured or born into slavery were crucial in the formation of capital. Slave labor mined the coin. Slaves were the major factor of production in precisely the sectors where economic growth and capital accumulation were most prominent, the large workshops and the most competitive and profitable estates. 'Coin made the purchase of slaves easier and allowed owners either to group them in workshops or to profit in coin ... from the work of slaves...' (Davies 2008: 358). This process accelerated from Classical to Hellenistic times (Descat 2008), widening inequality and probably suppressing the more distributed forms of governance.

\section{WHAT KIND OF MODERNISM?}

The ancient Mediterranean and Mesoamerica both share a scholarly history in the substantivist/formalist, primitivist/modernist debate, with one difference: that for the Greco-Roman world there has been more participation by economic historians and more deliberate use of economic theory. For both areas the literature of the past decade or two seems to weigh decidedly against the substantivist side, with much more discussion of market institutions and processes, profit-seeking economic actors, transaction costs, economic growth, and innovation. No one says these ancient societies operated just like industrial capitalist societies or even like the citystate systems of early modern Europe - not that kind of modernism.

For ancient Greece, a new consensus has emerged around new institutional economics. Nowhere is this better stated than in Alain Bresson's The Making of the Ancient Greek Economy: Institution, Markets, and Growth in the City-States, published in French in 2007-2008, the English translation brought out by Harvard University Press with a bit of updating in 2016. Bresson's is a masterwork, Braudelian in scope, a rich mix of data catalyzed by economic theory. He draws principally on texts and secondarily on archaeology, he writes clear exegesis on the history of ideas about ancient Greece those of scholars and the participants themselves - and about economic history. He lays his historical foundations in ecological 
structure - climate and climate change, the obligatory environmental diversity, soils, winds, the capture of energy, the economics of transport by road and by ship, the Mediterranean trilogy of grain, grapes, and olives, livestock raising, fisheries, and manufacturing.

He situates the study in new institutional economics but employs a wide range of modern economic concepts. The focus is on institutions - city-states, taxes, private property, coined money, the agora and internal trade, and the emporium and other institutions facilitating long-distance trade. City-states were a social contract between citizens and government that created a protected space for private property. Institutions of exchange lowered transaction costs and increased the volume of trade. Both citizen and city-state were dependent on internal and foreign markets, self-sufficiency was then and now a myth.

These institutions, Bresson argues, produced economic outcomes that made the Greek world not modern but an outstanding way-mark on a two-steps-forward, one-step-back road to modernity. Population grew in a demographic regime that had lower mortality than other ancient societies and fertility that responded to war or prosperity by making quick adjustments to increase or lower the birth rate and avoid the Malthusian trap. This was a city-state system with a core around Athens that exported fabricated goods, especially textiles, and a periphery that channeled raw materials and grain to the core. That the largest silver mines were in the territory of Attica and silver coins were the basis of a now-monetized economy was no small matter. The increased trade plus technological innovations, as in the milling of grain and larger ships, created wealth. The increase in per capita wealth can be seen in material culture, with higher household consumption, and from Morris's $(2004,2005)$ database of 400 houses, a six-fold increase in house size from 800 to $300 \mathrm{BC}$. This was real economic growth, of which in the primitivist view ancient economies were incapable because elites lived for luxury not profit-making.

The new conventional wisdom for the ancient Greek world causally links together city-states, democracy, markets, private property, free trade, economic growth, wealth, and the institutions that promoted property and markets. An example is Josh Ober's 2015 Princeton University Press book. For Ober, Greece was wealthy because it was not an old-fashioned Oriental empire but a world of competing city-states that developed fair rules promoting low trans- 
action costs and free trade, which stimulated innovation leading to greater wealth, growth, and cultural efflorescence. Greece was exceptional, no one else has done this until modern times.

No curtain or camouflage screens us from this celebration of Western exceptionalism. It is written in the clear language of advancement, betterment, efficiency, and progress. Modernity is the terminus of a measuring stick of goodness along which societies and their institutions are placed.

For recent scholars of the Classical economy the focus on institutions was a way of sidestepping and moving past the primitivist/modernist debate. But which institutions? Authors writing under the NIE flag speak in favor of free trade but little of that 'peculiar institution', slavery. Finley saw ancient Greece and Rome as slave societies and devoted books to slavery, which he saw as a past not dead yet (Ancient Slavery and Modern Ideology, Finley 1998, originally published in 1980). The index of Ober's book (2015) in contrast has one reference to slavery, which he brings up as illustrative of the ancient Greek's implicit theory of human capital development:

Rationally chosen individual investment in human capital development can, in the aggregate, have powerfully positive economic effects through increasing societal levels of specialization and productivity. By investing in learning, each individual becomes correspondingly better at whatever endeavor in which he or she is engaged. Individuals who choose to invest in themselves, who have freedom to seek out different domains, and who have specific natural capacities (e.g., high intelligence) have reason to seek out those domains in which their capacities can be more effectively exercised (Ober 2015: 112).

As for slaves, their owners trained them in special skills and might have passed laws shielding them from 'arbitrary mistreatment'. 'We don't know how much practical protection this legislation actually afforded Athenian slaves, but the general point is that the economic value of increasing human capital, by establishing appropriate rules governing conduct, was manifestly appreciated by the Classical Greeks' (Ibid.: 113).

Thus, the issue of slavery becomes a backhanded argument for how far the ancient world had progressed along the yardstick to modernity. There might have been laws that, if they were en- 
forced, might have protected slaves from being whipped too much to work the next day, which is a pretty good example of fair rules.

Robin Osborne had raised doubts about being so laudatory. His essay 'Athenian Democracy - Something to Celebrate?' posits that Greek citizens could form collective polities and reach democratic decisions because they shared common interests and culture. But he says that the price of citizen homogeneity was the exclusion of metis, women, and slaves (Osborne 2010). Here Osborne refines a phrase of Ellen Wood, who wrote that the free farmer/head of house and democracy owed their existence to slavery: 'the freedom of the citizen and the degradation of the slave were but two sides of the same coin' (Wood 1988: 110). That is, slaves not only funded the general surplus wealth, but because the heads of households controlled bound labor they had the legal status as owners and citizens, as well as the material resources and time to engage in the body politic.

An even more particular link between democracy and slavery is described by Paulin Ismard in his Democracy's Slaves (2017). Ismard shows how it was slaves, specifically a very small and select category of public slaves owned by the city (dêmosioi), who were charged with the day-to-day running of the Athenian institutions of democracy. Ismard begins his book with a vignette in Athens, Georgia, Confederate States of America, in AD 1861, where according to historian Merton Coulter, the city owned a slave named Joe. Public slaves in Athens, Greece, were civil servants essential to the government; they had the expertise of procedure and the institutional knowledge, whereas the citizens whose turn it was to have a seat in the assembly would not have that level of political knowledge. The dèmosioi of course were but a small fraction of Attica's enslaved people.

In his Empire of Cotton: Global History (2014) Sven Beckert argues that slavery underwrote industrial capitalism and made it possible. His book circles us back to the Athens, Georgia, of Joe and the 1891 other enslaved people who lived in that city in AD 1860 (Coulter 1965), the Athens that was an important actor as a material and ideological central place in the Empire of Cotton, and the city where I now write.

If some of the West's self-defined great political-economic innovations, democracy and capitalism, were bankrolled by the institution of chattel slavery, then we have reason to look carefully at 
other, non-Western branches of human experience as we form concepts and theories about how political economies work.

I have compared only two city-state worlds. They are alike in scale, population, urbanization, wealth, and many other cultural features. They differ in their structured ways of meeting social objectives, especially regarding property. History has seen other citystate systems and other urban civilizations where city-states were not the predominant form. From the objective, non-ethnocentric, anthropological perspective there is no reason to favor or celebrate one of these rather than another. The metaphor of alternative pathways is not totally adequate either, because a path implies a previously demarcated route, whereas actual history, actual cultural evolution, in each alternative case is descent with modification of stumbles, missteps, lags, and uncertainties on a route not predestined and only understood in hindsight. I can see no reason to say that any of these stumbling blind tracks was more efficient or better than another unless one accepts the criterion of domination in the current historical moment. Who is winning a purported contest now is a dubious basis for a theoretical understanding of how things work. ${ }^{1}$

\section{NOTE}

${ }^{1}$ I am grateful to Richard Blanton, Jessica Dijkman, Edward Harris, Ken Hirth, Naomi Norman, Jackie Saindon, and David Small for conversations that significantly improved this study. Joanne Barron and John Millhauser let me present a brief version of this paper at the symposium 'The Archaeology of Money, Debt, and Finance', sponsored by the Society for Economic Anthropology, at the $83^{\text {rd }}$ annual meeting of the Society for American Archaeology, Washington, DC, in 2018 .

\section{REFERENCES}

Acton, P. 2016. Industry Structure and Income Opportunities for Households in Classical Athens. In Harris, E. M., Lewis, D. M., and Woolmer, M. (eds.), The Ancient Greek Economy: Markets, Households and City-States (pp. 149-165). New York: Cambridge University Press.

Archibald, Z. H. 2013. Ancient Economies of the Northern Aegean: Fifth to First Centuries BC. Oxford: Oxford University Press.

Beckert, S. 2014. Empire of Cotton: A Global History. New York: Alfred A. Knopf.

Berdan, F. F., Blanton, R. E., Boone, E. H., Hodge, M. G., Smith, M. E., and Umberger, E. 1996. Aztec Imperial Strategies. Washington, DC: Dumbarton Oaks. 
Blanton, R. E., and Fargher, L. F. 2008. Collective Action in the Formation of Pre-Modern States. New York: Springer.

Blanton, R. E., with Fargher, L. F. 2016. How Humans Cooperate: Confronting the Challenges of Collective Action. Boulder: University Press of Colorado.

Blanton, R. E., Fargher, L. F., and Heredia Espinoza, V. Y. 2005. The Mesoamerican World of Goods and Its Transformations. In Blanton, R. E. (ed.), Settlement, Subsistence, and Social Complexity: Essays Honoring the Legacy of Jeffrey R. Parsons (pp. 260-294). Los Angeles: Cotsen Institute of Archaeology, University of California.

Blanton, R. E., Kowalewski, S. A., Feinman, G., and Finsten, L. 1993. Ancient Mesoamerica: A Comparison of Change in Three Regions. $2^{\text {nd }}$ ed. Cambridge, UK: Cambridge University Press.

Boone, E. H. 1983. The Codex Magliabechiano and the Lost Prototype of the Magliabechiano Group. Berkeley: University of California Press.

Bresson, A. 2016. The Making of the Ancient Greek Economy: Institutions, Markets, and Growth in the City-States. Transl. by Rendall, S. (trans.). Princeton, New Jersey: Princeton University Press.

Cornell, T. J. 2000. The City-States in Latium. In Hansen, M. H. (ed.), A Comparative Study of Thirty City-State Cultures: An Investigation Conducted by the Copenhagen Polis Centre (pp. 209-228). Copenhagen: Royal Danish Academy of Sciences and Letters.

Coulter, E. M. 1965. Slavery and Freedom in Athens, Georgia, 1860-1866. Georgia Historical Quarterly 49: 264-293.

Davies, J. K. 2008. Classical Greece: Production. In Scheidel, W., Morris, I., and Saller, R. (eds.), The Cambridge Economic History of the Greco-Roman World (pp. 333-361). Cambridge: Cambridge University Press.

Descat, R. 2011. Labour in the Hellenistic Economy: Slavery as a Test Case. In Archibald, Z. H., Davies, J. K., and Gabrielsen, V. (eds.), The Economies of Hellenistic Societies, Third to First Centuries BC (pp. 207-215). Oxford: Oxford University Press.

Fargher, L. F., Heredia Espinoza, V. Y., and Blanton, R. E. 2011. Alternative Pathways to Power in Late Postclassic Highland Mesoamerica. Journal of Anthropological Archaeology 30: 306-326.

Feinman, G. M., and Nicholas, L. M. 2000. High-Intensity Household-Scale Production in Ancient Mesoamerica. In Feinman, G. M., and Manzanilla, L. (eds.), Cultural Evolution: Contemporary Viewpoints (pp. 119142). Boston: Springer.

Finley, M. I. 1998. Ancient Slavery and Modern Ideology. Princeton, New Jersey: Markus Wiener.

Garraty, C., and Stark, B. L. (eds.). 2010. Archaeological Approaches to Market Exchange in Pre-Capitalist Societies. Boulder: University Press of Colorado. 
Graeber, D. 2011. Debt: The First 5,000 Years. Brooklyn, New York: Mellville House.

Grube, N. 2000. The City-States of the Maya. In Hansen, M. H. (ed.), A Comparative Study of Thirty City-State Cultures: An Investigation Conducted by the Copenhagen Polis Centre (pp. 547-566). Copenhagen: Royal Danish Academy of Sciences and Letters.

Håkansson, N. T., and Widgren, M. (eds.). 2014. Landesque Capital: The Historical Ecology of Enduring Landscape Modifications. Walnut Creek, California: Left Coast Press.

Hansen, M. H. (ed.). 2000. A Comparative Study of Thirty City-State Cultures: An Investigation Conducted by the Copenhagen Polis Centre. Copenhagen: Royal Danish Academy of Sciences and Letters.

Hansen, M. H. 2006. Polis: An Introduction to the Ancient Greek City-State. Oxford: Oxford University Press.

Hansen, M. H. 2008. Analyzing Cities. In Marcus, J., and Sabloff, J. (eds.), The Ancient City: New Perspectives on Urbanism in the Old and New World (pp. 67-76). Santa Fe, New Mexico: School for Advanced Research Press.

Harris, E. M., and Lewis, D. M. 2016. Introduction: Markets in Classical and Hellenistic Greece. In Harris, E. M., Lewis, D. M., and Woolmer, M. (eds.), The Ancient Greek Economy: Markets, Households and City-States (pp. 1-37). New York: Cambridge University Press.

Harris, E. M., Lewis, D. M., and Woolmer, M. (eds.) 2016. The Ancient Greek Economy: Markets, Households and City-States. New York: Cambridge University Press.

Hirth, K. G. 2016. The Aztec Economic World: Merchants and Markets in Ancient Mesoamerica. New York: Cambridge University Press.

Hirth, K. G., and Pillsbury, J. (eds.). 2013. Merchants, Markets, and Exchange in the Pre-Columbian World. Washington, DC: Dumbarton Oaks.

Hirth, K. G., Smith, M. E., Berdan, F. F., and Nichols, D. L. 2017. Wrapping up Objects, Economy, and Empire: Scale, Integration, and Change. In Nichols, D. L., Berdan, F. F., and Smith, M. E. (eds.), Rethinking the Aztec Economy (pp. 278-291). Tucson: University of Arizona Press.

Hodge, M. G. 1984. Aztec City-States. Memoirs No. 18. Ann Arbor: Museum of Anthropology, University of Michigan.

Hodge, M. G. 1997. When is a City-State: Archaeological Measures of Aztec City-States and Aztec City-State Systems. In Nichols, D. L., and Charleton, T. H. (eds.), The Archaeology of City-States: Cross-Cultural Approaches (pp. 209-227). Washington, DC: Smithsonian Institution Press.

Inomata, T., and Houston, S. D. 2001. Royal Courts of the Ancient Maya. 2 vols. Boulder, Colorado: Westview Press. 
Isaac, B. L. 2013. Discussion. In Hirth, K. G., and Pillsbury, J. (eds.), Merchants, Markets, and Exchange in the Pre-Columbian World (pp. 435448). Washington, DC: Dumbarton Oaks.

Ismard, P. 2017. Democracy's Slaves: A Political History of Ancient Greece. Transl. by Todd, J. M. Cambridge: Harvard University Press.

King, E. M. (ed.). 2015. The Ancient Maya Marketplace: The Archaeology of Transient Space. Tucson: University of Arizona Press.

Kohler, T. A., Smith, M. E., Bogaard, A., Feinman, G. M., Peterson, C. E., Betzenhauser, A., Pailes, M., Stone, E. C., Prentiss, A. M., Dennehy, T. J., Ellyson, L. J., Nicholas, L. M., Faulseit, R. K., Styring, A., Whitlam, J., Fochesato, M., Foor, T. A., and Bowles, S. 2017. Greater Post-Neolithic Wealth Disparities in Eurasia than in North America and Mesoamerica. Nature 551: 619-623.

Kowalewski, S. A. 2012. A Theory of the Ancient Mesoamerican Economy. Research in Economic Anthropology 32: 187-224.

Kowalewski, S. A. 2016. It Was the Economy, Stupid. In Fargher, L. F. and Heredia Espinoza, V. Y. (eds.), Alternative Pathways to Complexity: A Collection of Essays on Architecture, Economics, Power, and CrossCultural Analysis in Honor of Richard E. Blanton (pp. 15-40). Boulder: University Press of Colorado.

Kowalewski, S. A. 2020. Advances in City-State Research, with an Example from Mesoamerica. Journal of Archaeological Research 28: 3-52.

Kowalewski, S. A., Brannan, S. P., Cortés Vilchis, M. Y., Diego Luna, L., García Ayala, G., López Zárate, J. L., Méndez Sobel, F., Stiver Walsh, L. R., Turck, E. B., Turck, J. A., and Vepretskiy, S. 2017. Regional Archaeology and Local Interests in Coixtlahuaca, Oaxaca. Latin American Antiquity 28: 353-372.

Kron, G. 2016. Classical Greek Trade in Comparative Perspective. In Harris, E. M., Lewis, D. M., and Woolmer, M. (eds.), The Ancient Greek Economy: Markets, Households and City-States (pp. 356-380). New York: Cambridge University Press.

Las Casas, Bartolomé de. 1986. Historia de Las Indias II. Caracas: Ayacucho.

Lewis, D. M. 2016. The Market for Slaves in the Fifth- and Fourth-Century Aegean: Achaemenid Anatolia as a Case Study. In Harris, E. M., Lewis, D. M., and Woolmer, M. (eds.), The Ancient Greek Economy: Markets, Households and City-States (pp. 316-336). New York: Cambridge University Press.

Lyttkens, C. H. 2013. Economic Analysis of Institutional Change in Ancient Greece: Politics, Taxation, and Rational Behavior. London: Routledge.

Marcus, J. 1998. The Peaks and Valleys of Ancient States: An Extension of the Dynamic Model. In Feinman, G. M., and Marcus, J. (eds.), Ancient States (pp. 3-13). Santa Fe, New Mexico: School of American Research Press. 
Marcus, J., and Sabloff, J. A. (eds.). 2008. The Ancient City: New Perspectives on Urbanism in the Old and New World. Santa Fe, New Mexico: School for Advanced Research Press.

Morris, I. 2004. Economic Growth in Ancient Greece. Journal of Institutional and Theoretical Economics 160: 709-742.

Morris, I. 2005. Archaeology, Standards of Living, and Greek Economic History. In Manning, J. G., and Morris, I. (eds.), The Ancient Economy: Evidence and Models (pp. 91-126). Stanford, California: Stanford University Press.

Morris, S., and Papadopoulos, J. K. 2005. Greek Towers and Slaves: An Archaeology of Exploitation. American Journal of Archaeology 109: 155-225.

Nicholas, L. M. 1989. Land Use in Prehispanic Oaxaca. In Kowalewski, S. A., Feinman, G. M., Finsten, L., Blanton, R. E., and Nicholas, L. M. (eds.), Monte Albán's Hinterland, Part II: Prehispanic Settlement Patterns in Tlacolula, Etla, and Ocotlan, the Valley of Oaxaca, Mexico (pp. 449-505). Memoir No. 23. Ann Arbor: Museum of Anthropology, University of Michigan.

Ober, J. 2011. Wealthy Hellas. Journal of Economic Asymmetries 8: 1-38.

Ober, J. 2015. The Rise and Fall of Classical Greece. Princeton, New Jersey: Princeton University Press.

O'Connor, R. A. 2000. A Regional Explanation of the Tai Müong as a CityState. In Hansen, M. H. (ed.), A Comparative Study of Thirty City-State Cultures: An Investigation Conducted by the Copenhagen Polis Centre (pp. 431-443). Copenhagen: Royal Danish Academy of Sciences and Letters.

Odum, E. P. 1993. Ecology and Our Endangered Life-Support Systems. $2^{\text {nd }}$ edition. Sunderland, MA: Sinauer.

Osborne, R. 2010. Athens and Athenian Democracy. Cambridge: Cambridge University Press.

Sahagún, Fr. Bernadino de. 1975. Historia general de las cosas de Nueva España. México, DF: Editorial Porrua.

Scheidel, W. 2008. Demography. In Scheidel, W., Morris, I., and Saller, R. (eds.), The Cambridge Economic History of the Greco-Roman World (pp. 38-86). Cambridge: Cambridge University Press.

Scheidel, W. 2013. Studying the State. In Bang, P. F., and Scheidel, W. (eds.), The Oxford Handbook of the State in the Ancient Near East and Mediterranean (pp. 5-57). New York: Oxford University Press.

Scherer, A. K., and Golden, C. 2009. Tecolote, Guatemala: Archaeological Evidence for a Fortified Late Classic Maya Political Border. Journal of Field Archaeology 34: 285-305.

Schumpeter, J. A. 1942. Capitalism, Socialism, and Democracy. New York: Harper. 
Smith, M. E. 2008. Aztec City-State Capitals. Gainesville: University Press of Florida.

Smith, M. E., Dennehy, T., Kamp-Whittaker, A., Colon, E., and Harkness, R. 2014. Quantitative Measures of Wealth Inequality in Ancient Central Mexican Communities. Advances in Archaeological Practice 2: 311-323.

Smith, M. E., and Hicks, F. 2017. Inequality and Social Class in Aztec Society. In Nichols, D. L., and Rodríguez-Alegría, E. (eds.), The Oxford Handbook of the Aztecs (pp. 423-436). Oxford University Press.

Stark, B. L. 2013. Economic Growth in Mesoamerica. Paper presented at the $78^{\text {th }}$ annual meeting of the Society for American Archaeology, Honolulu.

Steere, B. A., and Kowalewski, S. A. 2012. Wealth Stratification in Ancient Mesoamerica. Social Evolution \& History 11 (1): 20-48.

Temin, P. 2013. The Roman Market Economy. Princeton, NJ: Princeton University Press.

Thompson, F. H. 2003. The Archaeology of Greek and Roman Slavery. London: Duckworth.

Tokovinine, A., and Beliaev, D. 2013. People of the Road: Traders and Travelers in Ancient Maya Words and Images. In Hirth, K. G., and Pillsbury, J. (eds.), Merchants, Markets, and Exchange in the Pre-Columbian World (pp. 169-200). Washington, DC: Dumbarton Oaks.

Trawick, P., and Hornborg, A. 2015. Revisiting the Image of Limited Good: On Sustainability, Thermodynamics, and the Illusion of Creating Wealth. Current Anthropology 56: 1-27.

Van der Spek, R. J. 2011. The 'Silverization' of the Economy of the Achaemenid and Seleukid Empires and Early Modern China. In Archibald, Z. H., Davies, J. K., and Gabrielsen, V. (eds.), The Economies of Hellenistic Societies, Third to First Centuries BC (pp. 402-420). Oxford: Oxford University Press.

Weigand, P. C. 1968. The Mines and Mining Techniques of the Chalchihuites Culture. American Antiquity 33: 45-61.

Weigand, P. C. 1993. Evolución de una civilización prehispánica: Arqueología de Jalisco, Nayarit, y Zacatecas. Zamora: Colegio de Michoacán.

Williams, E. (ed.). 2004. Bienes estratégicos del antiguo Occidente de México: producción e intercambio. Colegio de Michoacán, Zamora.

Wood, E. M. 1988. Peasant-Citizen and Slave: The Foundations of Athenian Democracy. London: Verso.

Yoffee, N. 2005. Myths of the Archaic State: Evolution of the Earliest Cities, States, and Civilizations. Cambridge: Cambridge University Press.

Zuiderhoek, A. 2017. The Ancient City. Cambridge: Cambridge University Press. 